\title{
Gain weight and sleep desynchronization in workers of a tertiary hospital
}

\author{
Maria Carlota Borba Brum, Camila Morelatto de Souza, Claudia Carolina Schnorr, Fábio Fernandes Dantas Filho, \\ Gustavo Borchardt Bottega, Sheila Stoniosso, Karen Gomes Avila, Otávio Azevedo Bertoletti, \\ Lisandra Almeida Nunes, Ticiana C Rodrigues
}

From 20th Brazilian Diabetes Society Congress

Porto Alegre, Brazil. 11-18 November 2015

\section{Background}

The effects of night work or shift work on workers' health are unknown, recent findings have indicated that may affect glucose tolerance, lead to obesity, diabetes and metabolic syndrome (MS). The desynchronization of the circadian cycle has been related to some of these effects, as well as sleep deprivation and exposure to light at night.

\section{Objectives}

To study the association between shift work and chronic diseases and quality of life among health professionals of a university hospital and compare workers day and night shifts in relation to metabolic changes and altered sleep pattern.

\section{Materials and methods}

Cross-sectional study conducted between April 2013 and December 2014. Sociodemographic data were evaluated and for the quality of life we used the WHOQOL BREF. Cronotypes and daily preferences sleep were investigated by Chronotype Questionnaire Munich (MCTQ ). Sleep quality was assessed by questionnaire Pittisburgh Sleep Quality Index. Physical examination was performed and venous blood was collected in fasting for $12 \mathrm{~h}$ for laboratory analysis.

\section{Results}

129 women and 49 men were included, 108 of the day shift and 80 from night. Night workers had more income, were older, had more time in the institution, less sleep in h, higher BMI, larger waist circumference,

* Correspondence: tcostarodrigues@terra.com.br

SBEM, Porto Alegre, Brazil 


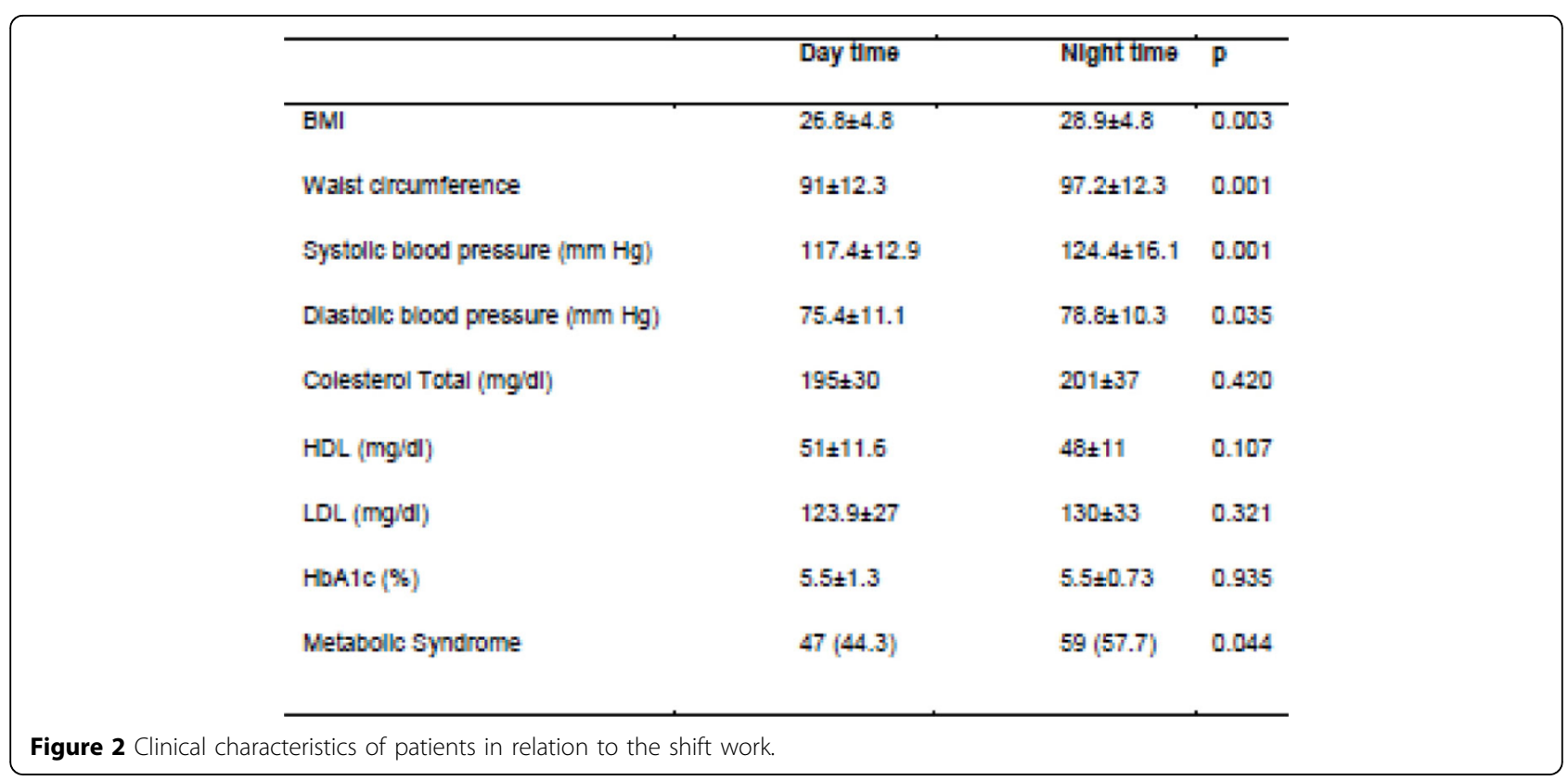

\begin{tabular}{lccc}
\hline & Day tIme & NIght time & P \\
\hline Midpoint WD & $3: 54(3: 00-5: 06)$ & $5: 54(4: 00-10: 30)$ & $<0.001$ \\
Sleep duration WD & $7: 00(5: 48-8: 18)$ & $5: 42(3: 48-7: 30)$ & 0.013 \\
Sunshine WD & $1: 00(0: 37-2: 00)$ & $1: 30(0: 41-3: 07)$ & 0.312 \\
Midpoint on day off & $4: 42(4: 00-5: 48)$ & $4: 30(3: 54-6: 24)$ & 0.840 \\
Sleep duration on day of & $8: 18(7: 00-9: 12)$ & $6: 54(6: 00-8: 54)$ & 0.008 \\
Sunshine on day off & $3: 00(2: 00-5: 00)$ & $3: 00(1: 00-5: 37)$ & 0.750 \\
Jet leg & $0: 48(0: 00-1: 48)$ & $-6: 15(-15: 00-00: 24)$ & $<0.001$ \\
Alarm clock uses & $59(64.8)$ & $17(43.6)$ & 0.040 \\
Wake up alarm & $27(45.0)$ & $6(31.6)$ & 0.443 \\
\hline Quantitative variables described by median (interquartile range P25- P 75). WD:working day
\end{tabular}

Figure 3 Characteristics for the chronotype and duration of sleep.

doi:10.1186/1758-5996-7-S1-A124

Cite this article as: Brum et al:: Gain weight and sleep

desynchronization in workers of a tertiary hospital. Diabetology \&

Metabolic Syndrome 2015 7(Suppl 1):A124.
Submit your next manuscript to BioMed Central and take full advantage of:

- Convenient online submission

- Thorough peer review

- No space constraints or color figure charges

- Immediate publication on acceptance

- Inclusion in PubMed, CAS, Scopus and Google Scholar

- Research which is freely available for redistribution

Submit your manuscript at www.biomedcentral.com/submit 